\title{
Analysis of the volume of autogenous cancellous bone grafts with or without the use of PTFE-e membranes in ovariectomized rats
}

Análise do volume ósseo trabecular de enxertos ósseos autógenos recobertos ou não por membranas de PTFE-e em ratas ovarectomizadas

Maria Aparecida Neves JARDINI ${ }^{1}$, Andrea Carvalho DE MARCO ${ }^{1}$, Antonio Braulino de Melo FILHO ${ }^{2}$, Rodrigo Dias NASCIMENTO ${ }^{1}$, Warley David KERBAUY ${ }^{1}$, Mauro Pedrine SANTAMARIA ${ }^{1}$

1 - Institute of Science and Technology - UNESP - Univ Estadual Paulista, School of Dentistry - Department of Diagnosis and Surgery - São José dos Campos - SP - Brazil.

2 - Institute of Science and Technology - UNESP - Univ Estadual Paulista - School of Dentistry - Department of Social Science and Pediatric Dentistry - São José dos Campos - SP - Brazil.

\section{ABSTRACT}

Objective: To verify the influence of the osteopeny induced by the bone repairing of the receptor site/autogenous bone graft block interface either associated with or without PTFE-e membrane through the analysis of the trabecular bone volume. Material \& Methods: 48 Wistar rats weighing approximately $300 \mathrm{~g}$ were submitted to parietal bone graft which was fixed to the lateral wall of the left mandibular ramus. The animals were randomly divided into four groups: Group 1: simulated ovariotomy (SHAM) and autogenous bone graft; Group 2: SHAM and autogenous bone graft through PTFE-e membrane recovering; Group 3: ovariotomy (OVZ) and autogenous bone graft; Group 4: OVZ and autogenous bone graft and PTFE-e membrane recovering. The animals of each group were killed at the following periods: 21, 45 and 60 days, comprising 4 animals per group. The pieces were decalcified and included; the cuts were stained with $\mathrm{HE}$ and submitted to histological and histomorphometric analysis through light microscopy. Results: ANOVA test showed that the variables accounting for both the condition (OVZ and SHAM) and the period (21,45 and 60 days) were statistically significant; the Tukey test (5\%) showed that the period of 21 days was statistically different from 45 and 60 days; however, they were not statistically different between each other. The descriptive histological analysis showed grafting integration in all animals. Conclusion: the process of graft integration with the receptor site was negatively affected by the induced osteopeny presence and presence or absence of PTFE-e membrane did not interfered in the integration process.

\section{KEYWORDS}

Metabolic bone diseases; Bone graft; Repairing.

\section{RESUMO}

Objetivo: Avaliar quantitativamente e descrever qualitativamente o processo de reparação óssea da interface leito receptor e enxerto ósseo autógeno em bloco associado ou não a membrana de PTFE-e, em ratas, portadoras de osteopenia induzida. Material e Metodos: 48 ratas Wistar pesando aproximadamente $300 \mathrm{~g}$, receberam um enxerto ósseo do osso parietal o qual foi fixado à parede lateral do ramo mandibular esquerdo. Os animais foram divididos aleatoriamente em quatro grupos: Grupo 1: ovariectomia simulada (SHAM) e enxerto ósseo autógeno; Grupo 2: SHAM e enxerto ósseo autógeno com recobrimento por membrana de PTFE-e; Grupo 3: ovariectomia (OVZ) e enxerto ósseo autógeno; Grupo 4: OVZ e enxerto ósseo autógeno com recobrimento por membrana de PTFE-e. Os animais de cada grupo foram sacrificados nos períodos: 21, 45 e 60 dias, com 4 animais por grupo. As peças foram descalcificadas e incluídas; os cortes corados com HE e submetidos à análise histológica e histomorfométrica em microscopia de luz. Resultados: Os testes ANOVA mostraram que as variáveis referente a condição (OVZ e SHAM) e ao período (21,45 e 60 dias) foram estatisticamente significantes, pode-se estabelecer com o teste de Tukey (5\%) que o período de 21 dias difere estatisticamente dos períodos de 45 e 60 dias, que entre si não diferem. A análise histológica descritiva mostrou integração do enxerto em todos os animais.Conclusão: $O$ processo de integração do enxerto ao leito foi negativamente afetado na presença de osteopenia induzida e o uso ou não da membrana de PTFE-e, não interferiu neste processo de integração.

\section{PALAVRAS-CHAVE}

Doenças ósseas metabólicas; Enxerto ósseo; Reparação. 


\section{INTRODUCTION}

$\mathrm{T}$ he osseointegrated implants are excellent alternative for rehabilitation, either functionally or aesthetically, of single or multiple prosthetic spaces. In cases in which the existing bone volume does not provide the installation of fixtures in adequate site, reconstructive technique should be used aiming at this adequate volume [1]. Several techniques have been already described using materials of autogenous, homogenous, heterogeneous or synthetic origin $[2,3]$. Notwithstanding, the autogenous bone has been considered as "Gold Standard" because it has shown the best results regarding to the bone availability and quality of the grafted area at the moment of the installation of the implants, especially when used in the augmentation of local width (onlay grafts).

The influence of postmenopausal osteoporosis on the repairing process of autogenous block bone grafts has not been completely known and understood.

Taking into consideration the incidence increasing of this condition in women at menopause period [4] as well as the increasing of the rehabilitation through osseointegrated implants consequently leading to reconstructive procedures it is worthy evaluating the biological behavior during the repairing process of autogenous onlay grafts in these situations. Thus, the aim of this study was to assess the influence of the induced osteopeny on the repairing process of autogenous bone grafts either associated with or without PTFE-e membrane through the analysis of the trabecular volume in Wistar rats submitted to ovariotomy (OVZ) and simulated ovariotomy (SHAM).

\section{MATERIAL \& METHODS}

48 female adult Wistar rats, aging ninety days, weighing about 300 grams were used. This study was approved by the Ethical Committee in Research of the School of Dentistry of São José dos Campos - UNESP under protocol number 035/2204-PA/CEP.
The animals were randomly divided into two experimental groups which were subdivided into subgroups:

a)test group: 24 ovariectomized rats (OVZ) OVZ - E: 12 animals submitted to bone grafting only;

OVZ - ME: 12 animals submitted to bone grafting associated with the recovering by expanded polytetrafluoroethylene (PTFE-e) membrane

b) control group controle: 24 rats submitted to simulated ovariotomy (SHAM)

SHAM - E: 12 animals submitted to bone grafting only;

SHAM - ME: 12 animals submitted to bone grafting associated with the recovering by PTFE-e membrane.

The animals of the test group (ovariotomy) had their ovary tractioned towards outside the abdominal cavity and after the suture of the vessels of this area, the ovary was excised. The animals of the control group were submitted to simulated ovariotomy (SHAM) through the tractioning of the ovaries towards outside the abdominal cavity, however without their excision. This procedure aimed to submit the animals of the control group to the same stress condition of those of the test group. The grafting procedures were executed thirty days after either the true or simulated ovariotomy. The parietal bone (autogenous) was the donor site while the left mandibular angle was the receptor site. At that moment, the animals were weighed to assess the weight gain. The bone graft gathered from the parietal bone was removed with the aid of a trephine bur of external diameter of $4.1 \mathrm{~mm}$ (Neodent - Brazil) under copiously irrigation with saline solution and fixed onto the receptor site $[5,6]$.

The OVZ-ME and SHAM-ME subgroups received a membrane for grafting recovering while OVZ-E and SHAM-E subgroups only used the graft.

After the surgical procedures to perform the bone grafts, all animals received a single dose of 
$1 \mathrm{mg} / \mathrm{kg}$ of antibiotics (Pentabiótico Veterinário - Fort Dodge), through intramuscular injection.

The animals of both groups were killed through anesthetic overdose at 21, 45 and 60 days. For each period, four animals were killed by experimental group.

Next, the left hemi-mandibles were removed and kept for fixation in 10\% buffered formaldehyde for at least $48 \mathrm{~h}$. Each specimen was identified.

The pieces were decalcified with 10\% EDTA, pH 7.8 in a microwave device (PELCO 3441, Ted Pella, Inc., CA, USA), in the Oral Pathology Laboratory of the School of Dentistry of the University of São Paulo.

After the preparation of the animal for euthanasia, the abdomen was opened to assess visually the uterine horns which contributed for confirming the ovariotomy success.

After the complete decalcification, the pieces were cross-sectionally cut on the central area of the bone graft. Each fragment was included in paraffin block in the direction of the cut surface and submitted to histological process of serial cuts with $5 \mu \mathrm{m}$ of thickness, resulting in a total of four laminas with five cuts per block. The cuts were stained in hematoxylin and eosin (HE - Merck \& Co, Inc.) and the histological and histomorphometric analysis were executed under light microscopy. The histological analysis was initially performed with x100 magnification to enable a total view of the field.

For each animal, the two most central fields were selected in each lamina, that is, the right and left sites of the central perforation of the graft fixation were selected. When this selection was not possible, the middle of the graft was estimated and one field was adjacent to each other. Next, the study area was increased to $\mathrm{x} 200$ and $\mathrm{x} 400$ magnification comprising the interface between the receptor site and the graft.

The quantitative analysis of the cuts were carried out with the aid of the images captured by a light microscope Zeiss Axiophot 2 (Carl Zeiss, Oberköchen, Germany), composed of x10 ocular and x40 objective lens, under a fixed focus coupled to a digital camera Axio can ICc1(Carl Zeiss, Oberköchen, Germany) which enabled the image visualization on a Samsung TV screen.

The images were stored into JPEG format and they were submitted to histomorphometric analysis with the aid of NIH Image $J$ software version 1.31 of public domain.

Such software allowed the quantification of the trabecular volume (volume occupied by the trabecular bone, either mineralized or not, expressed as the percentage of the volume occupied by the bone trabeculi [5]), which was evaluated through point-counting and planimetry, by using reticles with 70 points resulting from the intersection between the vertical and horizontal lines. The intersection points which matched to the new-formed bone tissue were counted. The relationship between the number of points onto the structure analyzed and the total number of the reticle corresponded to the proportion of the bone matrix formed in the interface between the receptor site and graft. Then, this number was transformed into percentage (\%) of the 70 points.

The areas where the intersections matched either other types of tissue or areas without any tissue were considered as negative regarding to the new-formation of bone tissue (Figure1).

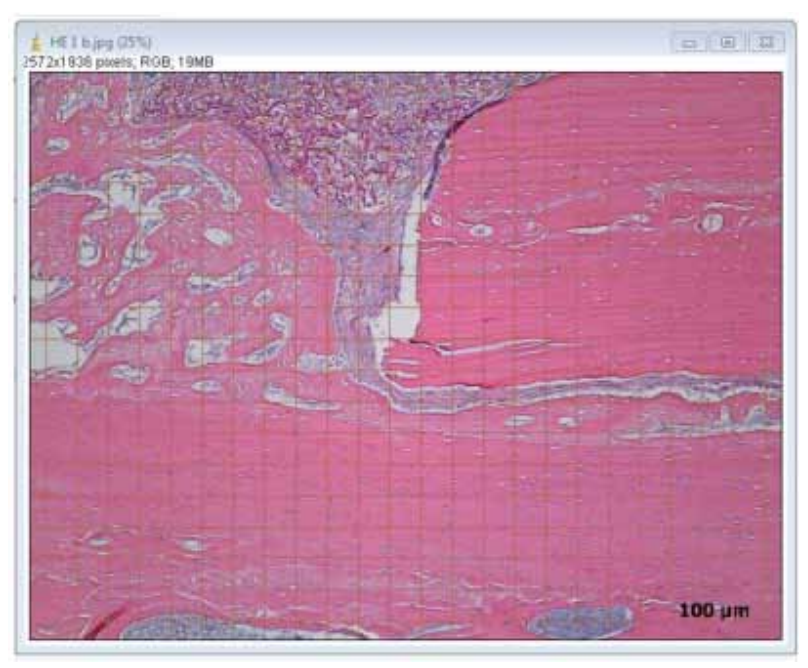

Figure 1-Planimetry to count points. 
The images had codes so that the identification of the groups (Shan or OVZ) were not possible, therefore resulting in a blind analysis of the data.

The percentage value of the bone matrix new formed in the area analyzed, per animal, was obtained through the mean values of the four laminas assessed.

\section{Statistical analysis}

The statistical analysis had $2 \times 2 \times 3$ factorial design, composed of the experimental variables (study factor) - conditions of the animals (SHAM or OVZ), the presence or absence of PTFE-e membrane (E and ME) and the euthanasia sacrifice (21, 45 and 60 days). The response variable was the value of the trabecular bone in interface area between the receptor site and the graft obtained through NIH Image $J$ software version 1.31 , of public domain. The experimental conditions were randomly designed, that is, 12 experimental conditions under four repetitions.

This resulted in 48 data which were submitted to the statistical analysis through the following software: MINITAB (Minitab, version $14.12,2004$ ) and STATISTICA (StatSoft, version 8.0, 2000).

The descriptive statistics consisted in the calculation of the means and standard deviation, while the inferential statistics was performed through three-way analysis of variance (ANOVA) and Tukey test, both at the level of significance of $5 \%$.

The study of the interaction effect among study variables was performed through mean

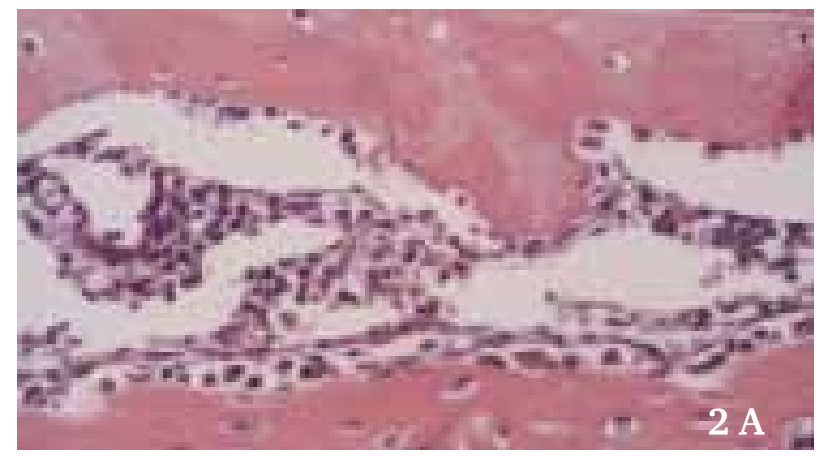

graphic executed in Prism software (version 4.00, 2003 Graph Pad Software Inc.).

\section{RESULTS}

Clinically, the procedures occurred without any problems, without infection, animals killing or suture dehiscences. Forty-eight animals resulted into 48 pieces for histological processing.

The effects of the ovariotomy were assessed through the clinical analysis of the weight control before and after castration and uterine atrophy at the moment of the euthanasia of the animals. The trabecular volume was assessed in the interface between the receptor site and graft through histology and histomorphometry.

\section{Descriptive histological analysis}

The descriptive histological analysis of the receptor site-graft interface was conducted at the following periods:

\section{1 days}

SHAM-E: The receptor site-graft interface showed connection points which enabled visualizing a new-formed bone tissue with several marrow spaces covered by cells similar to osteoblasts, lacunas filled by massive osteocytes, however without lamellar organization

SHAM-ME: In the interface, it was also possible to identify the new-formed tissue with connection points between the receptor site and the graft, with characteristics similar to group E. Some specimens displayed a greater bone formation in the interface. The mixed aspect of the areas of immature bone with mature bone was also observed, as well as the presence of massive osteocytes and interposed conjunctive tissue.

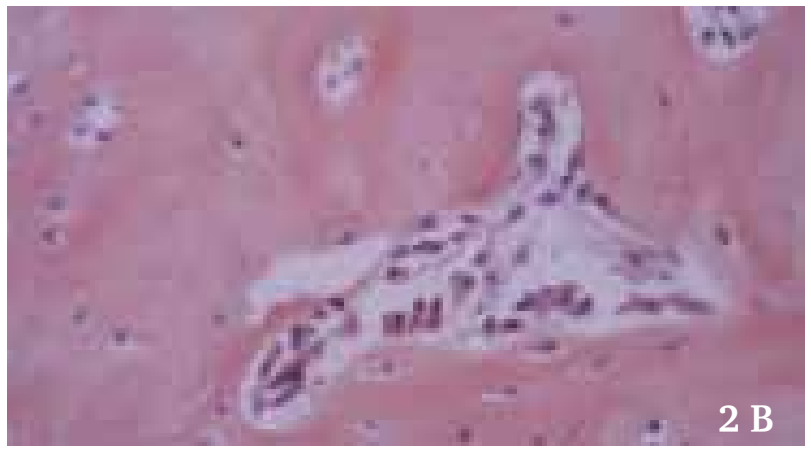

Figure 2 - Bone new formed in the interface receptor site-bone graft with medullar spaces of varied sizes surrounded by osteoblasts. a) SHAM 21 E group; b) SHAM 21 ME group. x400 magnification. 
OVZ-E: In the interface, a deposition of immature bone tissue was noted with few connection points between the receptor site and the graft, with interposition of conjunctive tissue.

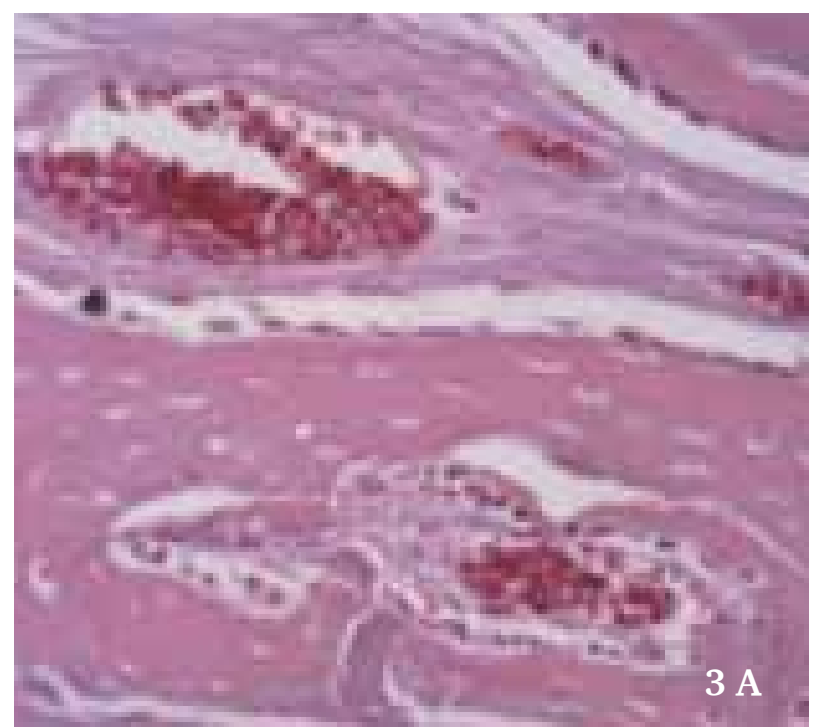

OVZ-ME: It showed a greater amount of medullar spaces than SHAM ME group, both in the graft and in the bone tissue new formed in the interface.

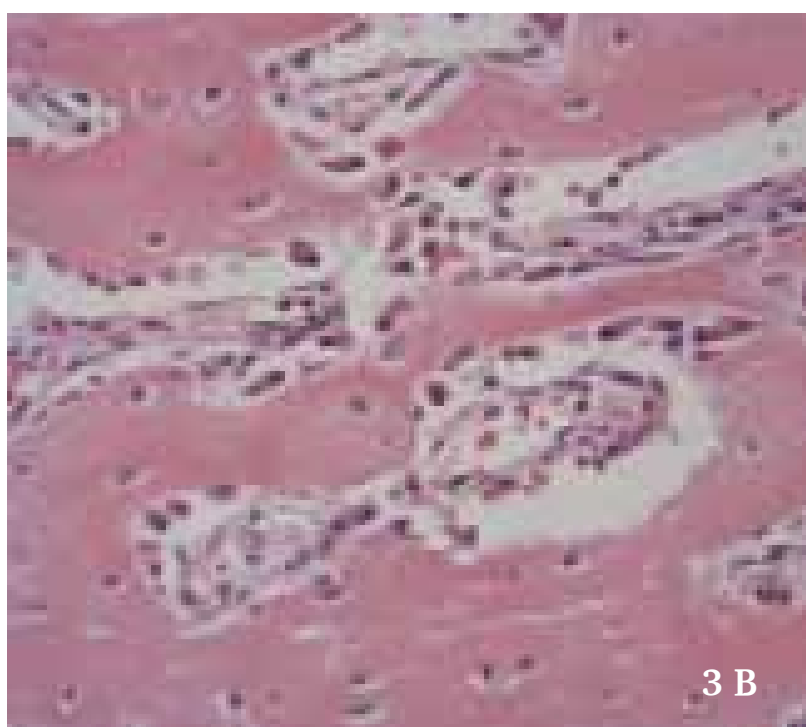

Figure 3 - Presence of conjunctive tissue in the interface receptor site-graft in OVZ 21E group (a) and bone new formed in the interface with medullar spaces of varied sizes surrounded by osteoblast in OVZ21E (a) and OVZ 21 ME (b) groups. x400 magnification.

\section{5 days}

SHAM-E: The new formed bone in the interface replacing the graft was of compact and mature type.

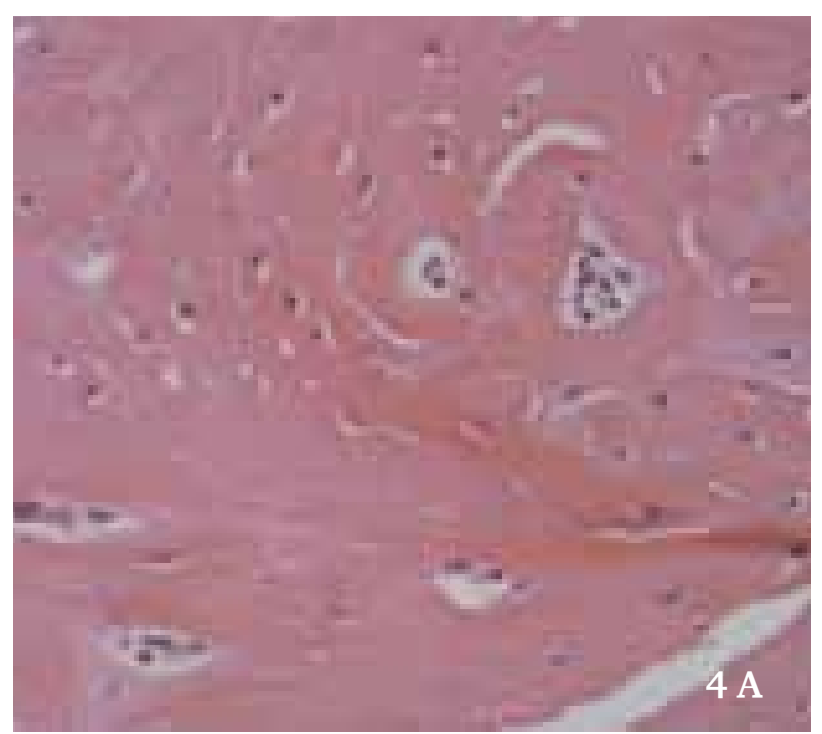

SHAM-ME: the receptor site had the same characteristics of the previous group including the integration of the graft to the site

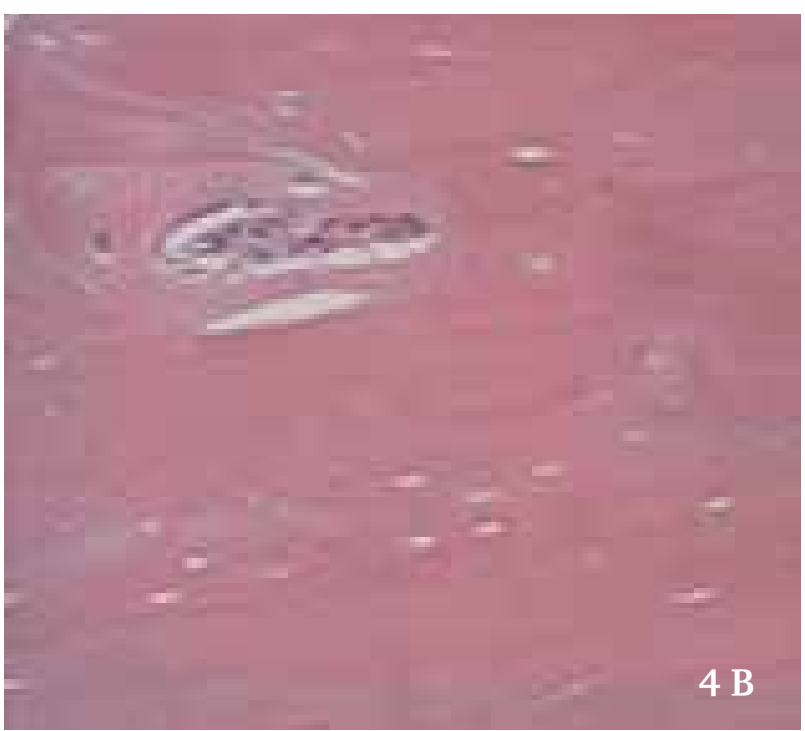

Figure 4 - Newly-formed bone in the interface receptor site- graft with compact aspect in SHAM 45 E group (a), and more mature aspect in SHAM 45 ME group (b). x400 magnification. 
OVZ-E: the new formed bone in the receptor site-graft interface was compact in some areas. However, the integration of the graft to the receptor site was apparently smaller than that of the SHAM group, with greater amount of conjunctive tissue interposed.

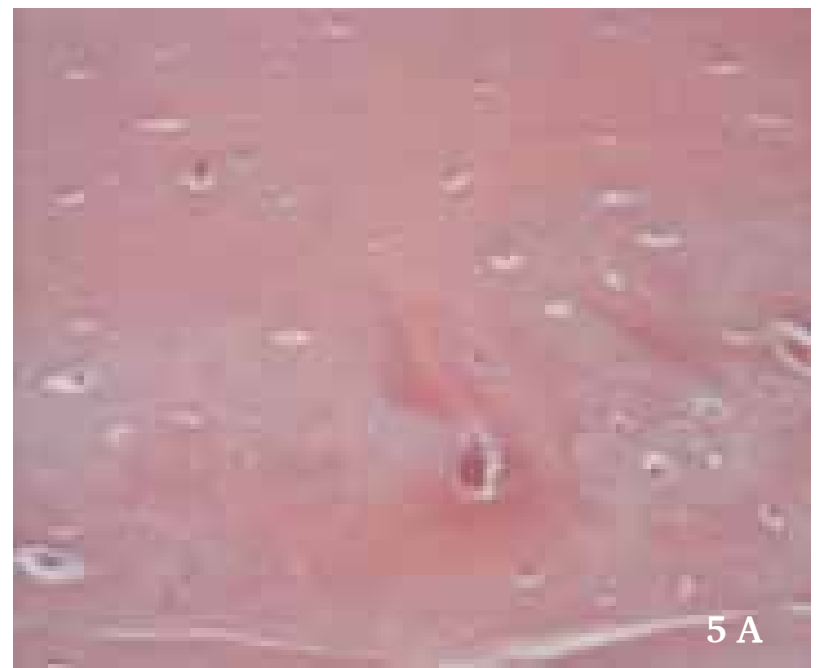

OVZ-ME: The characteristics found were similar to those of OVZ-E group; however, it was observed a greater amount of points of integration in the interface as well as signs of bone remodeling.

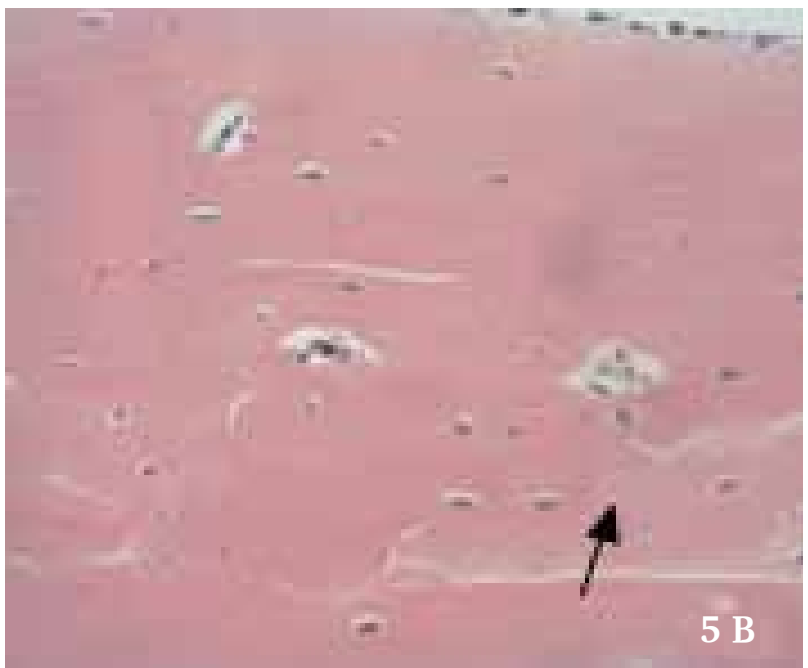

Figure 5 - Area of compact bone tissue in the interface receptor site-graft in OVX $45 \mathrm{E}$ group (a) and compact bone tissue with remodeling signs ( ) in OVX 45 ME group (b). X400 magnification.

\section{0 days}

At this period, in all groups, the graft was integrated to the receptor site. SHAM-E and OVZ-E:. The interface in SHAM E group was

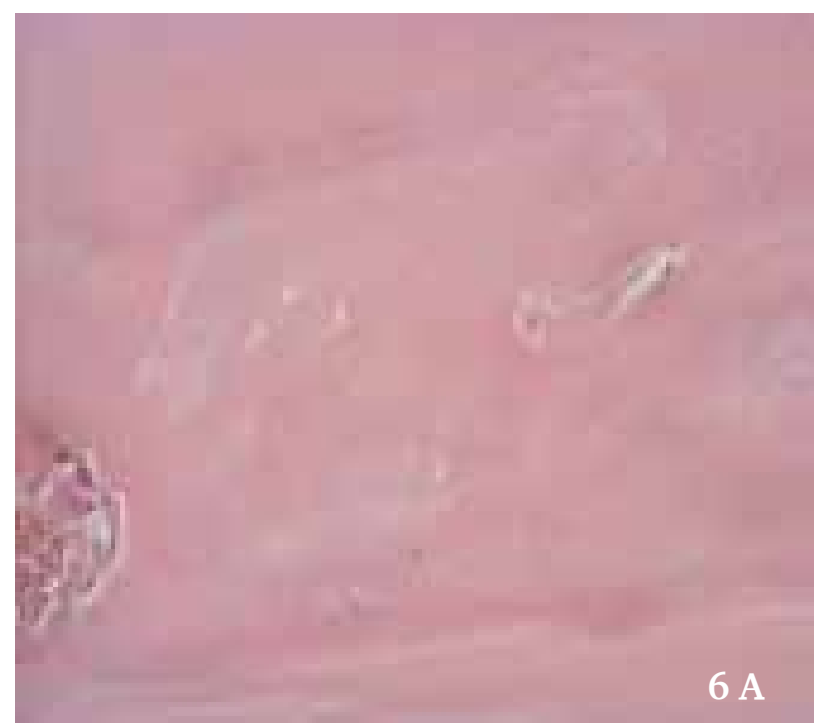

more compact than that of OVZ E group, which showed some medullar spaces.

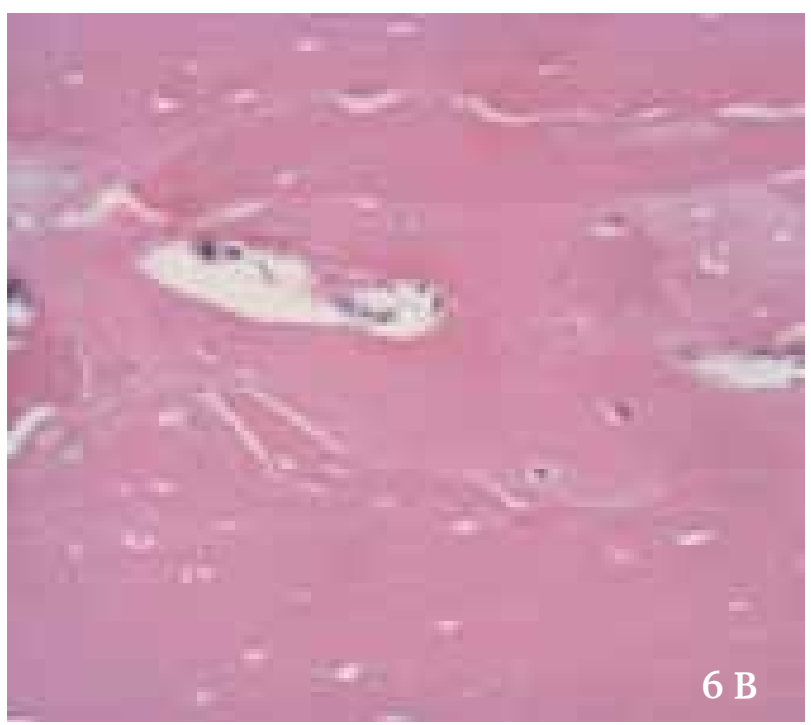

Figure 6 - Area of compact bone tissue in the interface between receptor site-graft in SHAM 60 E and OVZ60 E group. x400 magnification 
SHAM-ME and OVZ-ME: The new formed tissue in the interface was completely integrated with the receptor site which made difficult to

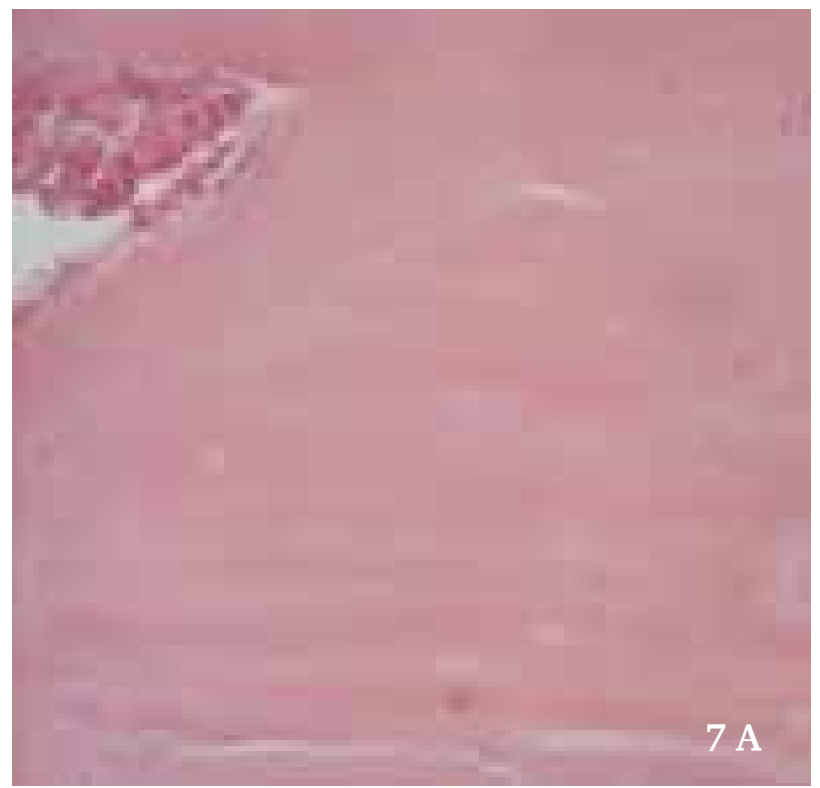

delimitate precisely the integration areas in most times.

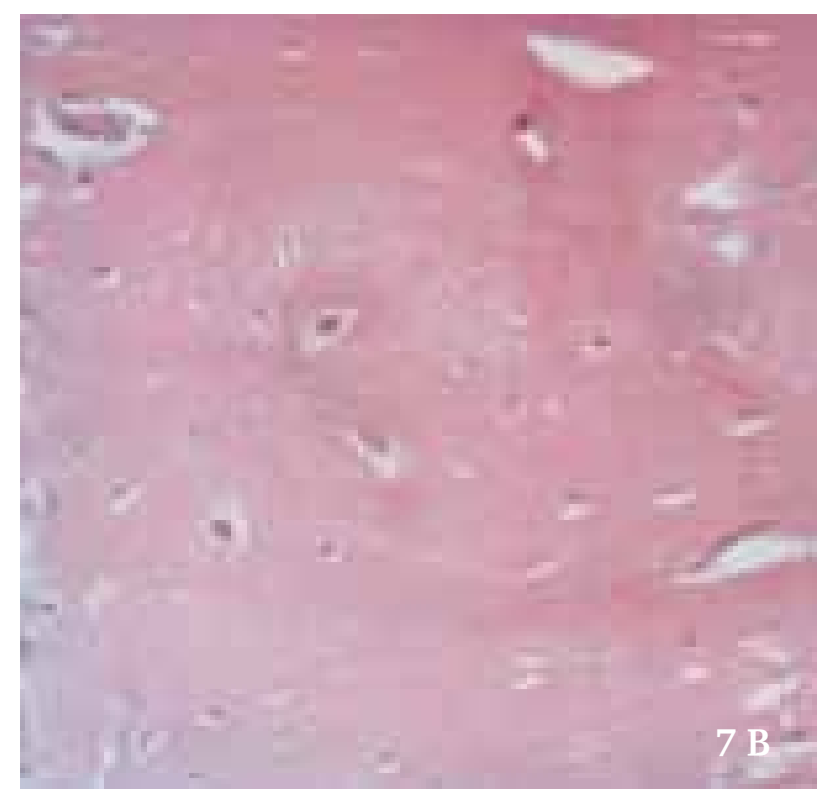

Figure 7 - Area of compact bone tissue in the interface between the receptor site- graft with some medullar spaces in SHAM 60 ME (a) and OVZ 60 ME (b) groups. x400 magnification

\section{Histomorphometric analysis}

The values of the trabecular volume are shown in Figures 7 and 8.

\section{OVZ}

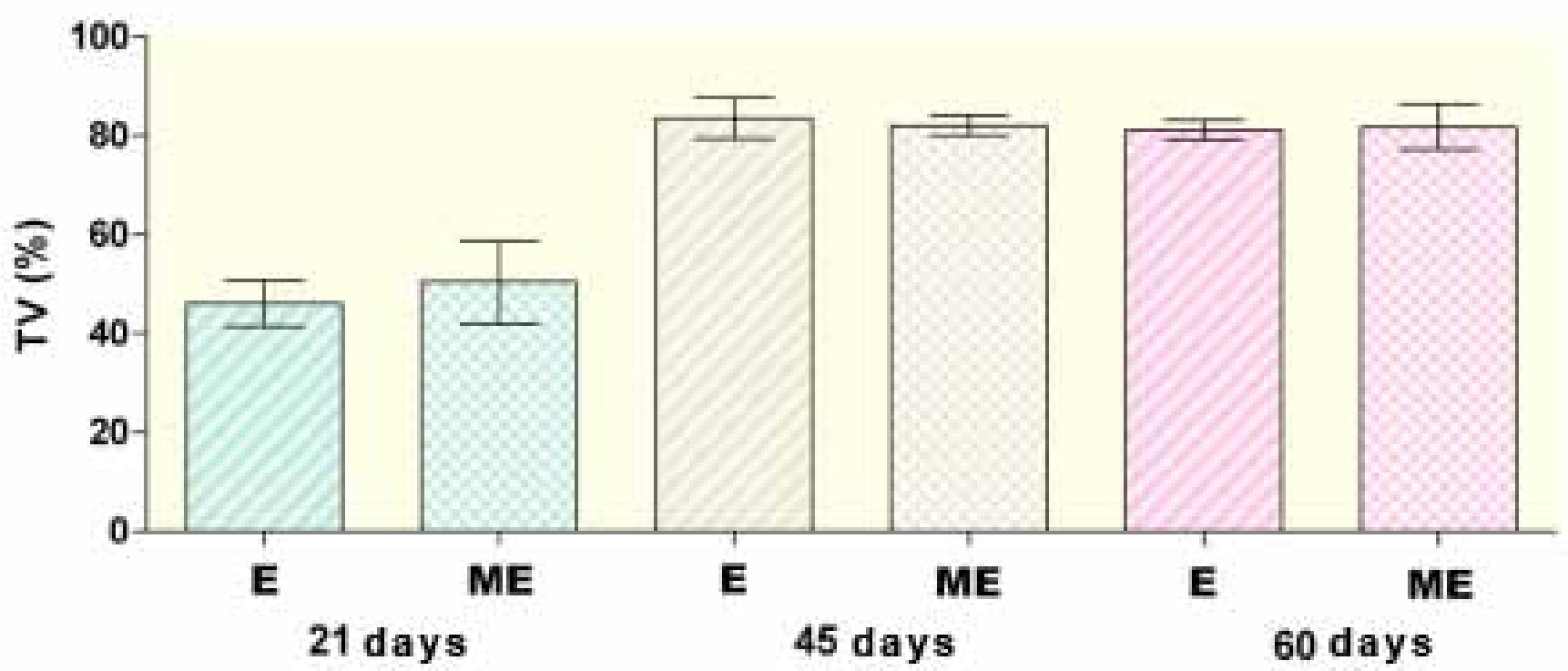

Figure 8 - OVZ group. Graph of columns (mean \pm standard deviation) of TV values (\%) according to the experimental conditions established by the two study variables: Membrane ( $\mathrm{E}$ and ME) and killing period ( 21 days, 45 days and 60 days). 


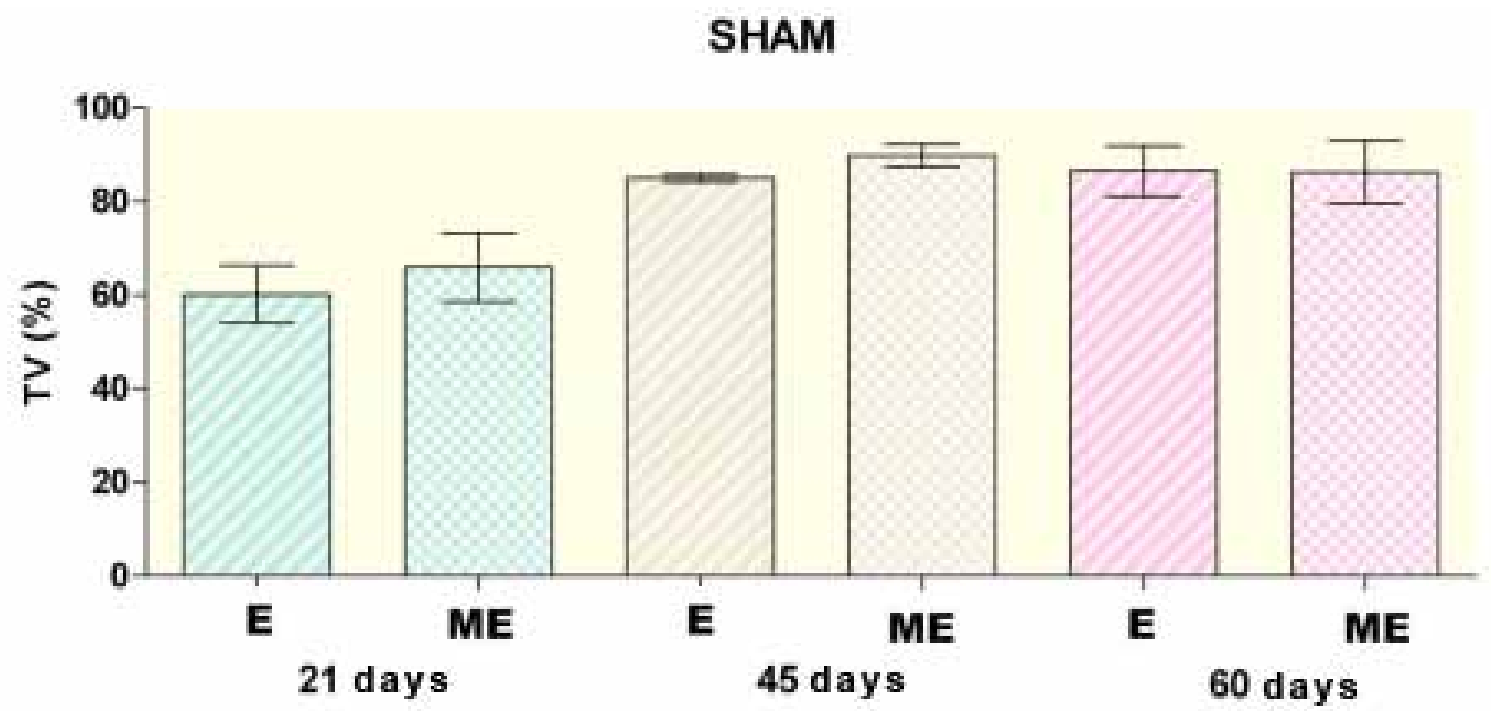

Figure 9 - Graph of columns (mean \pm standard deviation) of TV values (\%) according to the experimental conditions established by the two study variables: Membrane ( $\mathrm{E}$ and $\mathrm{ME}$ ) and killing period ( 21 days, 45 days and 60 days).

Taking the previous figures into observation, it can be noted the absence of atypical values for most of the experimental conditions, either for SHAM or OVZ groups.

To evaluate the relationship among the experimental values: condition (SHAM or OVZ), PTFE-e membrane (E or ME) and killing periods (21,45 and 60 days) and their effects on the trabecular volume, the data of this present study was submitted to analysis of variance after the consideration of the distribution of the residues. The residue values coming from the adjustment of the model adopted were examined to assess the suitability of the model for the valid statistical inferences. Accordingly, it was determined that the original data enabled an adequate adjustment because the uniformity of the residues (homoscedasticity) was verified through the graph of the residue values regarding to the values adjusted.

The results of three-way ANOVA are shown in Table 1.

Table 1 - ANOVA test. ConditionO C, MembraneO M and PeriodOP

\begin{tabular}{|c|c|c|c|c|c|}
\hline Effect & gl & SQ & $\mathbf{Q M}$ & $\mathbf{F}$ & $\mathbf{P}$ \\
\hline C & 1 & 0.07905 & 0.07905 & 30.60 & $0.00001^{\star}$ \\
\hline$M$ & 1 & 0.00635 & 0.00635 & 246 & 0.1257 \\
\hline$P$ & 2 & 0.88966 & 0.44483 & 172.21 & $0.00001^{\star}$ \\
\hline CXM & 1 & 0.00157 & 0.00157 & 0.61 & 0.4411 \\
\hline CXP & 2 & 0.02718 & 0.01359 & 5.26 & $0.0099^{*}$ \\
\hline$M X P$ & 2 & 0.00492 & 0.00246 & 0.95 & 0.3952 \\
\hline СXMXP & 2 & 0.00269 & 0.00135 & 0.52 & 0.5981 \\
\hline Residue & 36 & 0.09299 & 0.00258 & & \\
\hline Total & 47 & 1.10441 & & & \\
\hline
\end{tabular}


It can be verified that the effect of the interaction among the three study variables was not statistically significant ( $\mathrm{p}$-value $=0.598$ $>0.05$ ).

ANOVA test demonstrated that the sole effect of the interaction of two statistically different variables was regarding to C (OVZ and SHAM) and $P$ (21, 45 and 60 days), in addition to their main effects.

The effect of the CxP interaction can be seen in Figure 9.

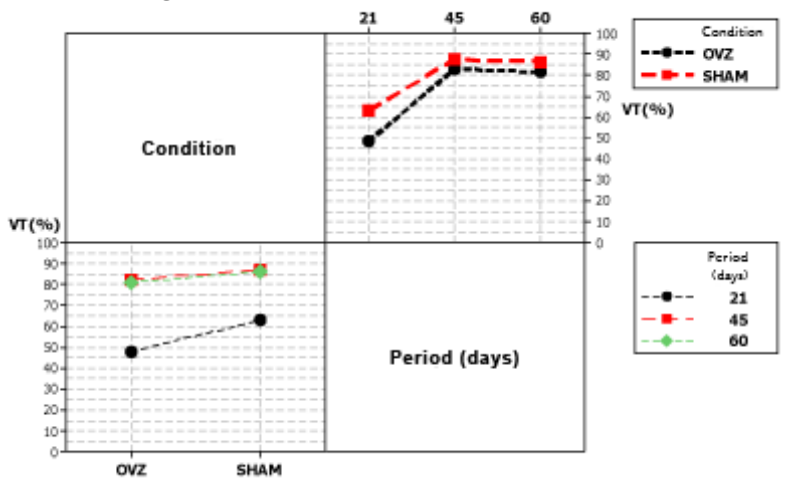

Figure 10 - Graph of the means concerning to the condition (OVZ or SHAM) and period (days) for the trabecular volume values (\%) of the interface between the receptor site and graft.

Concerning to the main effect of the variable period, Tukey test displayed that the 21-day period was statistically different from 45 and 60-days periods, which were not statistically different between each other.

When the mean values of the six experimental conditions established by the two study variables, CxP, Tukey test demonstrated that SHAM 21 day condition was statistically different from OVZ 21 day condition, as shown in Table 2.

Table 2 - Formation of the groups of same performance regarding to the trabecularvolume (TV) through Tukey test (5\%) for the data of condition and period

\begin{tabular}{cccc|} 
Condition & Period (days) & TV mean(\%) & $\begin{array}{c}\text { Homogenous } \\
\text { groups }^{*}\end{array}$ \\
\hline \multirow{2}{*}{ OVZ } & 21 & 0.4820 & $\mathrm{C}$ \\
& 45 & 0.8277 & $\mathrm{~A}$ \\
& 60 & 0.8145 & $\mathrm{~A}$ \\
SHAM & 21 & 0.6304 & $\mathrm{~B}$ \\
& 45 & 0.8735 & $\mathrm{~A}$ \\
& 60 & 0.8637 & $\mathrm{~A}$ \\
\hline
\end{tabular}

* means followed by different letters are statistically different among each other.
The other conditions (45 and 60 days), either in SHAM or OVZ groups were not statistically different among each other $(A \neq B$ $\neq \mathrm{C})$.

\section{DISCUSSION}

Because of the increasing of the life expectance of the population, currently, women have lived more than one third of their life at menopause [6], and consequently many of them has been at risk of developing osteoporosis These women may require complex dental procedures involving osseointegrated implants and bone grafts. Considering this issue, it is worthy understanding the influence of this condition on the process of bone repairing. In this study, the interface between autogenous bone grafts and the receptor site associated or not with membranes in ovariectomized Wistar rats.

The choice for employing the rat as experimental model was based on the fact that it has already been established in the literature due to its low cost, easy of storage and good availability [7]. Additionally to this, the similarities in the osteopeny pathogenesis found between the human being and the rat were also considered. Although the female rat does not undergo the natural menopause, after the ovarian removal and consequently estrogen deficiency, it shows a decreasing in the bone mass which after a period of fast loss undergoes deceleration and become stable at a plateau phase [8].

The bone alterations found in these animals after estrogen deficiency have been called as osteopeny instead of osteoporosis because unlike to the human woman, they do not undergo trauma due to low impact. There have been other similarities between postdeficiency estrogen osteopeny of rats and postmenopause osteoporosis of human women. The bone loss experienced by ovariectomized rats is most remarkable in vertebrae than in femur, which is consistent with the greatest loss of trabecular than cortical bone at the initial stages of post-menopause osteoporosis [9]. 
The augmentation of atrophic alveolar ridges with autogenous bone grafts is largely studied in literature on animals [10-13] and humans, by utilizing intra- and extraoral donor areas [1,14-20]. In this study, the calvarium was employed as donor area and the mandible as receptor area because these bones have the same embryonic origin and this type of graft suffers smaller resorptions [10,13,21].

Concomitantly with the studies on onlay bone grafts, the principle of guided tissue regeneration started to be applied also on the bone tissue, so-called guided bone regeneration (GBR). The use of PTFE-e membrane in GBR is based on the biocompatibility of the material, the ability of maintaining the space for osteogenic cells and fluids migration at the same time that they promote the isolation of cells without osteogenic potential [22-25].

To achieve successfully the desired increasing of the bone volume, it is mandatory a good integration between the receptor site and the graft. The facts contributing for this success are correlated to the vascularization, stabilization and fixation of the graft; embryologic origin and availability of the bone cells. The results obtained in this study showed that the presence of osteopeny negatively affect the beginning (21 days) of the integration process between the graft and the receptor site. Notwithstanding, at the latest evaluations (45 and 60 days), there were no differences between OVZ and SHAM rats.

At the moment of graft surgery, the animals already showed a more active osteoclast genesis because according to Most et al. [26], the deficiency of sexual steroids induce an increasing in the osteoclast genesis at the initial period just after the castration, which normalizes in 30 days. The smallest value of trabecular bone observed in OVZ rats in 21 days could be attributed to this fact. Wronski et al. [9] (1988) observed osteopeny and increasing of the rate of bone resorption at 14 days after surgery, which became gradually more pronounced until around 100 days. At the 21 day period, the OVZ rats showed mean values of trabecular volume of 46.05 for group $\mathrm{E}$ and 50.35 for group ME, while group SHAM exhibited 60.16 for group $E$ and 65.93 for group ME, with statistically significant differences $(\mathrm{p}=0.00001)$.

The bone graft employed in this study was of intramembranous origin, which according to the literature [27-30] has the greatest osteogenic potential than that of bones of endochondral origin. The revascularization of the cortical graft is the result of the peripheral resorption produced by osteoclasts and the vascular infiltration of the pre-existing haversian canals. De Marco et al. 2005 [30] showed that the revascularization of the bone graft in the interface with the receptor site occurs because of the proliferation of the vascular buds coming from the receptor site. This dynamics of the reconstruction observed inside the graft is called creeping substitution. Additionally, there are a limited number of endosteal cells available for aiding the formation of vascular anastomoses when compared with the medullar graft [31]. This last aspect is in agreement with which was observed in this study because the graft employed was constituted by two cortical layers involving a central medullar area. Other fact to be considered in the integration and remodeling of autogenous block bone grafts is the decorticalization of the receptor site. A greater incorporation of the graft was observed when perforations in the cortical plate of the receptor site and also in the graft [12] was executed $[32,33]$, aiming to the exposure of the medullar spaces to make easy the local angiogenesis. The importance of the graft immobilization also aims to the maintenance of the vascular anastomoses formed and consequently the nutrient and oxygen supply for the cells accounting for repairing [3].

In this study, the perforations executed in the middle of both the graft and the receptor site for its fixation were enough for vascular supplying because of the reduced thickness of both the graft and receptor site. This fact could be evidenced by the complete integration of the graft at the final observation periods in both groups (SHAM and OVZ).

The GBR association with autogenous block graft did not interfere in the trabecular 
volume of the interface between the receptor site and graft both in group SHAM and OVZ ( $\mathrm{p}=$ 0.13). Nascimento et al. (2009) [27] reported the importance of the membrane in the maintenance of the grafted bone tissue volume also favoring the new formed bone under the membrane. In this study, the fact of the membrane did not influence on the trabecular volume could be attributed to an optimum adaptation between the receptor site and the graft achieved by their fixation by the suture thread. Thus, the membrane would have a greater importance at the outer surface by isolating the contact of the graft with the surrounding tissues. This experimental observation is based on the literature by studies demonstrating the predictability of GBR in the lateral reconstruction of the alveolar ridge [25, 34-37]; as well as in the vertical reconstruction of the alveolar ridge [38,39].

Also, the descriptive histological evaluation of the repairing process in the interface area between the autogenous block bone grafts and the receptor site was carried out.

It could be noted that at the 21 day period, both in group SHAM-E and group OVZ-E, the interface showed deposition of immature bone tissue with focal union points between the receptor site and the graft together with interposed conjunctive tissue; also, groups SHAM-ME and OVZ-ME exhibited a greater amount of union points at the interface. It was observed a greater amount of medullar spaces both in the graft and in the new formed bone tissue in group OVZ than in group SHAM. At this period, the differences between groups were evident. By analyzing the final observation periods (45 and 60 days) there were no differences between groups OVZ and SHAM. The graft was totally integrated to the receptor site at 45 days in both groups because of the presence of bone neoformation attaching the receptor site to the graft. Concerning to the osteopeny influence, it could be noted that the integration of the graft with the receptor site as well as the graft behavior when associated or not with PTFE-e membrane was similar in both conditions (OVZ and SHAM). Therefore, the integration process of the autogenous bone graft was not altered in the animals of group OVZ when compared to those of control group. Notwithstanding, further studies are necessary because no conclusion can be drawn on the osseointegration of implants installed in these sites reconstructed in osteopenic animals.

\section{CONCLUSION}

Within the limits of this present study, it can be concluded that the initial process of integration of the graft to the receptor site was negatively affected by the presence of induced osteopeny; either the presence or the absence of the PTFE-e membrane did not interfere in this integration process.

Financial support: FUNDUNESP (process number 00219/05).

\section{REFERENCES}

1. Breine U, Brånemark PI. Reconstruction of alveolar jaw bone. Scand J Plast Reconstr Surg. 1980;14:23-48.

2. Curtis TA, William RW. Autogenous bone grafts for atrophic edentulous mandibles:a review of twenty patients. J Prosthet Dent. 1983;49:212-6.

3. LaTrenta GS, McCarthy JG, Breitbart AS, May M, Sissons HA. The role of rigid skeletal fixation in bone-graft augmentation of the craneofacial skeleton. Plast Rec Surg. 1989;84:578-88.

4. Szejnfeld VL. Osteoporose: diagnóstico e tratamento. São Paulo: Sarvier; 2000.

5. Jardini MAN, De Marco AC, Lima LA. Early healing pattern of autogenous bone grafts with and without e-PTFE membranes: a histomorphometric study in rats. Oral Surg Oral Med Oral Pathol Oral Radiol Endod. 2005;100:666-73.

6. Nascimento RD, Cardoso PE, De Marco AC, de Lima LA, Jardini MAN. Influence of osteopenia in autogenous bone graft healing with or without expanded polytetrafluoroethylene membranes: histologic and histomorphometric study in rats. Int J Oral Maxillofac Implants. 2009;24:1074-82.

7. WORLD HEALTH ORGANIZATION. Prevention and Management of Osteoporosis: report of a WHO scientific group. WHO technical report series;921. Geneva; 2000.

8. Kalu DN, Liu CC, Hardin RR, Hollis BW. The aged rat model of ovarian hormone deficiency bone loss. Endocrinology. 1989;124(1):7-16.

9. SZEJNFELD, V. L. Osteoporose: diagnóstico e tratamento. São Paulo: Sarvier; 2000.

10. Wronski TJ, Schenck PA, Cintrón M, Walsh CC. Effect of body weight on osteopenia in ovariectomized rats. Calcif Tissue Int. 1987;40:155-9.

11. TURNER C H, ROBLING A. Mechanical loading and bone formation. Bonekey-Osteovision. 2004;1(9):15-23. 
12. Dado DV, Izquierdo R. Absorption of onlay bone grafos in immature rabbits: membranous versus enchondral bone and bone struts versus paste. Ann Plast Surg. 1989;23:39-48.

13. Hardesty RA, Marsh JL. Craniofacial onlay bone grafting: a prospective evaluation of graft morphology, orientation, and embryonic origin. Plast Reconstr Surg. 1990;85:5-14.

14. Alberius $P$, Dahlin C, Linde A. Role of osteopromotion in experimental bone grafting to the skull: a study in rats using a membrane technique. J Oral Maxillofac Surg. 1992;50(8):829-34.

15. Donovan MG, Dickerson NC, Hellstein JW, Hanson LJ. Autologous calvarial and iliac onlay bone grafos in miniature swine. J Oral Maxillofac Surg. 1993;51:898-903

16. Misch CM. Comparison of intraoral donor sites for onlay grafting prior to implant placement. Int J Oral Maxillofac Implants. 1997Jun;12:767-76.

17. Misch CM. The repair of localized severe ridge defects for implant placement using mandibular bone grafts. Implant Dent. 1995 Winter;4(4):261-7. Review.

18. Becker W, Schenk R, Higuchi K, Lekholm U, Becker BE. Variations in bone regeneration adjacent to implants augmented with barrier membranes alone or with demineralized freeze-dried bone or autologous grafts: a study in dogs. Int J Oral Maxillofac Implants, 1995 Mar/Apr;10(2):143-54.

19. Raghoebar GM, Batenburg $\mathrm{RH}$, Vissink $\mathrm{A}$, Reintsema $\mathrm{H}$. Augmentation of localized defects of the anterior maxillary ridge with autogenous bone before insertion of implants. J Oral Maxillofac Surg, Philadelphia. 1996 0ct;54(10):1180-6.

20. Williamson RA. Rehabilitation of the resorbed maxilla and mandible using autogenous bone grafts and osseointegrated implants. Int $J$ Oral Maxillofac Implants. 1996;11(4):476-88.

21. Garg AK, Morales MJ, Navarro I, Duarte F. Autogenous mandibular bone grafts in the treatment of the resorbed maxillary anterior alveolar ridge: rationale and approach. Impl Dent, 1998;7(3):169-74.

22. Pikos MA. Block autografts for localized ridge augmentation: part II. The posterior mandible. Implant Dent Baltimore. 2000;9(1):67-75

23. Donos N, Kostopoulos L, Karring T. Alveolar ridge augmentation by combining autogenous mandibular bone grafts and non-resorbable membranes. An experimental study in the rat. Clin Oral Impl Res. 2002;13:185-91.

24. Dahlin C, Alberius P, Linde A. Osteopromotion for cranioplasty. An experimental study in rats using a membrane technique. $J$ Neurosur. 1991;74:487-91.

25. Buser D, Bräger U, Lang NP, Nyman S. Regeneration and enlargemento of jaw bone using guided tissue regenerration. Clin Oral Implants Res, Copenhagen. 1990 Dec;1(1):22-32.

26. Buser D, Dula K, Belser U, Hirt HP, Berthold H. Localized ridge augmentation using guided bone regeneration. I. Surgical procedure in the maxilla. Int J Periodontics Restor Dent, 1993;3(1):29-45.
27. Buser D, Dula K, Hirt HP, Schenk RK. Lateral ridge augmentation using autografts and barrier membranes: a clinical study with 40 partially edentulous patients. J Oral Maxillofac Surg, Philadelphia. 1996 Apr;54(4):420-32.

28. Most W, Van der Wee-Pals L, Ederveen A, Papapoulos S, Löwik $C$. Ovariectomy and orchidectomy induce a transient increase in the osteoclastogenic potential of bone marrow cells in the mouse Bone. 1997 Jan;20(1):27-30 1997

29. Jilka RL. Biology of the basic multicellular unit and the pathophysiology of osteoporosis.Med Pediatr Oncol. 2003:41(3):182-5

30. Serletti J, Manson P, Leipziger L. Trauma surgery. In:Reddi AH Habal M, eds. Bone Grafts and Bone Substitutes. Philadelphia: W.B. Saunders;1992

31. McAllister B S, Haghighat K. Bone augmentation Techniques. J Periodontol. 2007;78(3): 377-96

32. De Marco AC, Jardini MAN, Lima LA Revascularization of autogenous block grafts with or without an e-PTFE membrane. Int J Oral Maxillofac Implants. 2005;20:867-74.

33. Burchardt $\mathrm{H}$, Enneking WF. Transplantation of bone. Surg Clin North Am, 1978 Apr;58(2):403-26.

34. Gordh M, Alberius P, Johnell 0, Lindberg L, Linde A. Osteopromotive membranes enhance onlay integration and maintenance in the adult rat skull. Int J Oral Maxillofac Surg. 1998 Feb;27(1):67-73.

35. De Carvalho PSP, Vasconcellos LW, Pi J. Influence of bed preparation on the incorporation of autogenous bone grafts: a study in dogs. Int J Oral Maxillofac Implants, Chicago. $2000 \mathrm{Jul} /$ Aug;15(4):565-70.

36. Lioubavina N, Kostopoulos L, Wenzel A, Karring T. Long-term stability of jaw bone tuberosities formed by "guided tissue regeneration”. Clin Oral Impl Res. 1999;10:477-86.

37. Hämmerle CHF, Jung RE. Bone augmentation by means of barrier membranes. Periodontol 2000.2003:33:36-53.

38. Imazato S, Fukunish K. Potencial efficacy of GTR and autogenous bone graft for autotransplantation to recipient sites with osseous defects: evaluation by re-entry procedure. Dent Traumatol. 2004;20:42-7.

39. Hürzeler MB, Kohal RJ, Naghshbandi J, Mota LF, Conradt J, Hutmacher D, et al. Evaluation of a new bioresorbable barrier to facilitate guided bone regeneration around exposed implant threads. An experimental study in the monkey. Int J Oral Maxillofac Surg. 1998 Aug;27(4):315-20.

40. Simion M, Fontana F, Rasperini G, Maiorana C. Vertical ridge augmentation by expanded-polytetrafluorethylene membrane and a combination of intraoral autogenous bone graft and deproteinized anorganic bovine bone (Bio Oss). Clin Oral Implants Res. 2007:18(5):620-9.

\section{Maria Ap. Neves Jardini \\ (Corresponding address)}

Departamento de Diagnóstico e Cirurgia / Disciplina de Periodontia

Av. Eng. Francisco José Longo, $\mathrm{n}^{\circ} 777$ - Jardim São Dimas,

São José dos Campos - SP, Brazil,

CEP: $12245-000$

Fone number: 55 (12) 3947-9046 / FAX: 55 (12) 3947-9010

Date submitted: 2013 Apr 11

e-mail: jardini@fosjc.unesp.br
Accept Submission: 2013 Aug 05 